\title{
Developing Concept of the Self: The Environmentally Influenced or Innately Developed
}

\author{
Dr. Jerald C. Moneva \\ Department of Education \\ Mandaue City Division, Cebu, Philippines \\ E-mail: monevajerald5@gmail.com \\ Clarisa D. Quesio (Corresponding author) \\ E-mail: clarisa.quesio@yahoo.com \\ Mariejun A. Navaris (Corresponding author) \\ Jagobiao National High School \\ North Road, Jagobiao Mandaue City \\ E-mail: mariejunnavaris4@gmail.com
}

Received: February 25, 2020

Accepted: March 21, 2019 Published: May 20, 2020

doi:10.5296/iss.v8i1.17069

URL: http://dx.doi.org/10.5296/iss.v8i1.17069

\begin{abstract}
Self-concept is the awareness of a person of himself/herself based on his/her experiences, knowledge, body image, skills and in the way they tend to identify themselves in different situations, Meanwhile environment is where the students interact with others and spend most of their time. Environment is also where the students learn and gain experiences. Family, friends and peers are the people who the students communicate with, the people where they share their personal experiences and the people they mostly along with. The researchers used a survey questionnaire as a tool to be answered by the Senior High School students in Jagobiao National High School the data gathered will be treated using the weighted mean, frequency, percentage and lambda to determine their correlation. The influence of the variables are noticeable not significant to each other. It means that if they don't develop their self-concept environmentally and innately, there are other factors that develop the achievement of the students on the concept of the self.
\end{abstract}


Keywords: Self-concept, Environmentally influenced, Innately developed, Students 


\section{Introduction}

Self-concept is generally thought of as individual perceptions of person's behavior, skills, and unique characteristics. It is essentially a mental picture of a person. Examples are beliefs such as "I am a kind friend" or "I am a smart person". They are part of an overall self-concept. Self-concept tends to be malleable when people are younger and still going through the process of self-discovery and identify information. As people form a better idea of who they are and what is important to them. Self-concept can be change by the impact of different factor in psychology like environmental development. Self-concept is a complex of personalities because of how a person describes himself/herself (Gore \& Cross, 2011).

Some Senior High school students still don't see the personal concept of themselves. They are not sure to which path they are going to choose. They are still in doubt to what specific course they are to take in college. They have a lot of passion. They have different interests. There are also a lot of schools. There are even others who are doubtful if they can go to college. Their parents can't support them. Thus, they are thinking of any relatives like aunties and uncles who can support them. If they remain hopeless for coming year, they won't study anymore but choose to work to continue their path in life.

The environment plays a very important role in one's personal growth. A healthy environment will produce problematic society. It recommends that developing a self-concept of the adolescents and building a good family performance should be implemented targeting the behaviors of adolescents (Henderson, Dakof, Schwartz, \& Liddle, 2006). Self-concept can affect the persons communication because of this impact some people are introvert, extrovert and some are both introvert and extrovert. If someone has a sense of humour the way he/she talks, the other people will see him/her as a humorous person (Sampthirao, 2016).

The study assesses to know the developing concept of the self, how environment and self-influence the students' self-concept. The environment is everything. It can be living or non-living things. Self is a basic personality or nature, especially considered in terms of what they are really like as a person.

\subsection{Theoretical Background}

This study is anchored on the theory of Self-concept theory proposed by Carl Rogers and Social Comparison theory proposed by Leon Festinger which is used by the researcher to the study. Self-concept theory was proposed in 1947 by famed psychologists, theorists and clinician. Carl Rogers posted a theory of how self-concept influences and, indeed, acts as a framework for one's personality. The image of who a person is contributes to his/her personality and their actions combined with their personality create a feedback loop into their image of their selves. Rogers believed that the personality is driven by the desire for self-actualization. This is the condition that emerges when we reach the full potential and the self-concept, self-worth, and ideal self all overlap (Ackerman, 2018).

Self-concept theory talks about how people develop their personalities, how they manage their personalities and people attempt for self-actualization on some with more success, achievement and victory than others. On the broadest level, self-concept is the overall idea 
people have about they are.

Social comparison theory was first proposed in 1954 by psychologist Leon Festinger suggested that people have an innate drive to evaluate themselves, and one of the key ways people do this is through social comparison, or analysing the self in relation to others. Society influences the self through its shared language and meaning that enable a person to take the role of others, engage in social interaction and reflect upon one as an object (Cherry, 2019). People often compare their selves to others in their social worlds, whether it is comparing our looks to those of celebrities we see in the media or our talents of our co-workers.

Social comparison theory states that individuals determine their own social and personal worth based on how they stack up than others. People sometimes compare themselves to others in social worlds they see whether comparing their looks to the celebrities they see in media or compare their talents to others.

Self-concept and self-comparison theory supports the study "Developing Concept of the Self: the Environment and the Self." Through these theories, people better understand why individuals have such personalities and where the concepts of themselves may come from. These theories give people an underlying foundation of analysis as to the way people think of themselves, where these thinking may come from, and how all these thoughts affect their other thoughts, words, actions, habits then attitudes. Aside from understanding, self-concept and self-comparison theory also guide where and how people gather facts and information to support their hypotheses and other analyses they may need throughout the study. People know better which aspect to go and they're given specific scope so they cannot overlap to other areas.

\subsection{Statement of Purpose}

The study intends to determine the relationship between developing concept of the self: The environment and the self.

Specially, the study seeks to answer the following problems:

1). To what extent do students perceive that they are developing their self-concept innately?

2). To what extent as students perceived that their development is environmentally influenced?

3). Do students develop self-concept more innately than environmentally influenced?

\subsection{Significance of the Study}

This study and its result shall benefit the following:

First, the students will benefit this study because they will know about developing self-concept. By this, they can assess abilities that will help them to develop self-concept. They will also have knowledge that self and the environment can affect their self-concept development.

Second, the parents will benefit this study because they will have different abilities and ideas 
in terms of self-concept development and find this as a guide to develop their self-concept and help students to develop their self-concept.

Third, the teachers shall learn that the student's self-concept development needs to do their part as parents to their children by showing guidance, inspiration and motivation for the students to be determined in developing self-concept.

Lastly, this study can be beneficial to community because this study will serve as guidance for the community especially in Jagobiao Mandaue City to identify the students' ability in a certain field.

\subsection{Definition of Term}

To further understand this research study, some terms are operationally defines. These are the following terms:

Self refers to the students experience as a single being that is separate from others, experienced with continuity through time and place

Self-concept refers to the student's personal knowledge of which they are, encompassing all their thoughts and feelings about themselves physically, personally, and socially. Self-concept also involves their knowledge of how they behave their capabilities, and their individual characteristics.

Environment refers to the people who influence the student's behaviors, thoughts, and feelings.

\section{Review of Related Literature and Studies}

\subsection{Self-Concept: Innately Influenced}

The concept of self is the idea of who a person is, defined what people know about their behaviors, attitudes and actions. Self-concept is generally the perceptions of a person based on experiences, body image and thoughts. Self-concept begins to develop in early childhood. This process continues throughout the lifespan. Self-concept can also be developed through interaction with the world or society and its behavioral attributes. Self-concept can also be defined as an all-encompassing awareness you had of yourself in the past; the awareness you have of yourself in the present, and the expectations you have of yourself in the future. Self-concept includes what the students think about themselves and/or others, what the students pay much attention, how they understand the events and the challenges of their lives, and how they handle failure and success.

Self-concept is a perception of the student's abilities and in some ways a perception of a person's individual uniqueness. Self-concept can also impact the person's actions and performance. Self-concept is supposed to be an essential thing for each individual because this can change a person's views, manners and responses to personal and social life (Mehrad, 2016). Self-concept is the key for the students to have an easy social and emotional development (Villegas, Tomasini, \& Lagunes, 2013). Self-concept is the way how a person sees his/her behaviour (Mishra, 2016). There is a proof that self-concept can have an effect on 


\section{MInstitute ${ }^{m+1}$ Macrothink}

the contentment, performance and attitude of a person (Beheshtifar, 2012). The students must be motivated to have a positive self-concept and good performance towards their subjects (Ayodele, 2011). Self-concept is important for the students, because it can help the students about their school transition (Onetti, 2019).

Self-concept of a person is steady but it also develops through time so it also changes over time (Demo, 1992). The proofs that changing of self-concept in private settings is not stable, some ask if development of behaviour does really happen under private circumstances (Tice, 1992). Teachers must help the students develop their self-concept focusing the important area that is related to the future achievement result of the students' performance (Mclerney, Cheng, Mok, \& Lam, 2012). The more known, cooperative and good in classwork are the students with high self-concept, they will also be determine of how far they will step outside their comfort zone to solve their problem or achieve a goal (Bala, 2014). Self-concept has an impact to the students mentally; social adjustment will be used as an intervention between mental health and self-concept of the students (Zhu, Wang, Liu, Chen, \& Liu, 2016). Applying a program about developing self-concept positively impacts the self-concept of the students (Coelho, Sousa, \&Figueira, 2014).

\subsection{Self-Concept: Environmentally Influenced}

It is also important for the parents to have an attachment with their son/daughter and help their son/daughter social development and physical capability in their academic needs (Jaiswal \& Choudhuri, 2017). Environment has an influence in developing self-concept. Self-concept is not innate it develops through interaction with other people (Kumari \& Chamundeswaris, 2013).) Type of school towards developing self-concept of the student has no significant difference (Murugan \& Jebaraj, 2017). People in school should give attention to the developing social self-concept of the students (Wei \& Marder, 2012). Self-concept in society should be developed because it impacts students ' interactions with family, teachers, peers and other people in the school (Miller, 2013). Support, fellowship, parenting and styles of teaching appeared to be required to help children build their self-concept (Augestad, 2017). The school must help students improve their self-concept by promoting activities such as awarding the students every event (Sari, Siswad, \& Sriati, 2018). Future studies are worthy to improve the people's understandings about the self-concept of the learners (Davies \& Lee, 2011). The environment can influence self-concept. Thus in this perspective, we can consider the student will not have a positive behaviour if he or she don't have a high self-concept (Ceresnik \& Ceresnikova, 2018). Environment deeply affects the adolescents' perception and self-concept at their school (Hur, 2005).

The interactions of the students to others have identified students concern and accountability to keep peace in their environment (Diswantika, 2019). The teachers and parents should deal with the students' self-concept since they affect the student's self-concept development (Laryea, Saani, \& Brew, 2014). The schools must inform the parents about the important role they have on the self-concept development of their son/daughter. Educators should tell the parents about the ways in which both fathers and mothers could support their son/daughter in self-concept development (Pesu, Aunola, Viljaranta, \& Nurmi, 2016). It is essential to 
encourage the students to do some sporting activities because it can benefit the students physically it can also help them develop a positive self-concept (Lazaro, Alonso, Gallego, Pol-del-Rio, \& Leon-del-Barco, 2017). Students who come from disfavour environment needs some mediation and an assistant of the teacher to develop a positive self-concept (Anitha \& Parameswari, 2013). Residences and school can affect the students' self-concept development and academic success (Srivastava \& Joshi, 2011). The programs that are focused on environment must be applied to improve social ability that is related to capability and ambition to have the wanted result (Joy, 2015). The programs at school must be restructured to cause school as places that are an objective is helping students learn about life (Bashir, 2011).

Developing concept of the self: the environmentally influenced and innately developed plays crucial roles in this study to indicate the importance of the self-concept development to know the differences and potentialities each one of them. Both self and environment have the abilities to develop the self-concept of a person. Overall, people can do everything in accordance to their self-concept.

\section{Research Methodology}

This section contains the research design, environment, respondents, instrument, data gathering and statistical treatment.

\section{Design}

The quantitative approach - descriptive survey is utilized by the researcher. It includes the researcher process or the procedure and analysis of data gathered. It was used in gathering data on developing concept of self: environmentally influenced or innately developed.

\section{Locale}

The researcher conducts the study in a certain high school in Cebu, Philippines that offers more strands including: Accountancy, Business and Management (ABM), Humanities and Social Sciences (HUMSS), General Academic Strand (GAS), and Science, Technology, Engineering and Mathematics (STEM). It also includes Junior High School.

\section{Respondents}

The respondents of this research study are Grade 11 and Grade 12 Senior High School students of each strand (GAS, HUMMS, ABM, STEM, and TVL-Drafting). This study uses an exact total of all the Senior High School students to be the respondents. The study has a total of 243 respondents.

\section{Instrument}

The researcher utilized the survey questionnaire for the main tool in gathering the data. The survey questionnaire was adopted from structure of the personal self-concept questionnaire by Goñi, Madariaga, Axpel, and Goñi. (2011). The survey questionnaire consists of two parts. Part 1 was the developing concept of the self: innately, and part 2 was the developing concept of the self: the environment. It is composed of 20 questions. The choices are 1-strongly 
disagree, 2-disagree, 3-neutral, 4-agree, and 5-strongly agree. This guided the students to know how they develop their self-concept. Checklist is used to verify that a number of specific lines of inquiry or actions are being taken by the researchers.

\section{Data Gathering Procedure}

The researcher asked the permission of the principal, the teachers involved and the Senior High School students before conducting the survey using assessment tool which will be answered by the respondents who are the students of Jagobiao National High School Senior High department.

Inside the classroom where the survey was conducted, the respondents were given a questionnaire where the answers will be written. After the questionnaire would be distributed, the researcher will give time and they are given a chance to ask for easy access and ready to answer concerns and clarification of the given questions. Afterwards, the questionnaire will be collected for the interpretation of the data.

\section{Statistical Treatment}

The data will be treated using the sum to get the ratings of individual respondent from each indicator, frequency and percentage is the number of respondents categorized according to the variables. Lambda test is also used to determine which variable; self is innately influenced or environmentally influenced.

\section{Presentation, Analysis and Interpretation of Data}

Table 1. Environmentally influenced

\begin{tabular}{llc}
\hline \multicolumn{1}{c}{ Indicators } & WM & Interpretation \\
\hline 1. I depend on other people. & $\mathbf{2 . 9 7}$ & Neutral \\
2. If I'm feeling down, I always need a friend to lean on. & $\mathbf{3 . 4 2}$ & Agree \\
3. In order to do anything, I first need other people's approval. & $\mathbf{3 . 1 8}$ & Neutral \\
4. I find it hard to do anything without other people's support & $\mathbf{3 . 3 9}$ & Neutral \\
5. I am more sensitive than the majority of people & $\mathbf{3 . 5 0}$ & Agree \\
6. I suffer too much when other people ignore me. & $\mathbf{3 . 4 8}$ & Agree \\
7. I try not to do anything that may hurt others. & $\mathbf{3 . 7 1}$ & Agree \\
8. I find it difficult to make decisions without other people's opinion. & $\mathbf{3 . 3 9}$ & Neutral \\
9. I am more honest than other people. & $\mathbf{3 . 5 9}$ & Agree \\
10. I know how to make decisions without other people's suggestion. & $\mathbf{3 . 7 5}$ & Agree \\
\hline Overall Weighted Mean & $\mathbf{3 . 4 4}$ & Agree \\
\hline
\end{tabular}

$\mathrm{N}=400$. Legend: 1-1.8=Strongly Disagree, 1.81-2.6=Disagree, 2.61-3.4=Neutral, 3.41-4.2=Agree, 4.21-5=Strongly Agree.

The table above shows the highest and lowest weighted mean. The first highest weighted mean is 3.75 interpreted as agree, the second highest weighted mean is 3.71 interpreted as 
agree, the third highest weighted mean is 3.59 interpreted as agree. The first lowest weighted mean is 2.97 interpreted as neutral, the second lowest weighted mean is 3.18 interpreted as neutral and the third lowest weighted mean is 3.39 interpreted as neutral. The overall weighted mean is 3.44 interpreted as agree. Mean to say, environment strongly influenced the developing self-concept of the students because the environment is where the students do their social interactions with others, share their feelings, knowledge, beliefs and perceptions.

Table 2. Environmentally influenced

\begin{tabular}{lll}
\hline Category & Frequency & Percentage \\
\hline Strongly Disagree & 0 & $0 \%$ \\
Disagree & 2 & $0.8 \%$ \\
Neutral & 60 & $24.7 \%$ \\
Agree & 153 & $63 \%$ \\
Strongly Agree & 28 & $11.5 \%$ \\
\hline Total & $\mathbf{2 4 3}$ & $\mathbf{1 0 0 \%}$ \\
\hline
\end{tabular}

The table above shows the number of students who develop their self-concept on the environment. The numbers of respondents who have answered strongly disagree in developing concept of self: The environmentally influenced is 0 or $0 \%$. Followed by the number of respondents of who have answered disagree in developing concept of self: The environment is 2 or $0.8 \%$. Also the number of respondents who have answered neutral in developing concept of self: The environment is 60 or $24.7 \%$. Then, the numbers of respondents who have answered agree in developing concept of self: The environmentally influenced is 153 or $63 \%$. Lastly, the numbers of respondents who have answered strongly agree in developing concept of self: The environmentally influenced is 28 or $11.5 \%$. This reveal the number of respondents in each category but the most answered by the respondents is agree in developing concept of the self: The environmentally influenced because people around the students listen, understand and help them in order to achieve their goals. They learn and experience more when they interact with others. With technology they can use social media to communicate and use websites or social media videos to gain knowledge and adapt to the change of modernization.

Adolescent's self-concept can be developed by the influence of the environment (Hur, 2005). Companionship and attention is needed to help students improve their self-concept (Augestad, 2017). People in school environment must help the student's improve their self-concept in environment (Wei \& Marder, 2012). 
Table 3. Innately developed

\begin{tabular}{lcc}
\hline \multicolumn{1}{c}{ Indicators } & WM & Interpretation \\
\hline 1. I am satisfied with what I am achieving in my life. & $\mathbf{3 . 7 8}$ & Agree \\
2. So far, I have achieved every important goal I have set on myself. & $\mathbf{3 . 5 2}$ & Agree \\
3. I am a trustworthy person & $\mathbf{3 . 8 9}$ & Agree \\
4. I have always overcome any difficulties I have encountered in my life. & $\mathbf{3 . 7 1}$ & Agree \\
5. I am a decent, honest person. & $\mathbf{3 . 7 8}$ & Agree \\
6. If I could start my life over again, I would not change very much & $\mathbf{3 . 5 3}$ & Agree \\
7. I am a strong person. & $\mathbf{3 . 8 1}$ & Agree \\
8. I feel proud of how I am managing my life. & $\mathbf{3 . 8 2}$ & Agree \\
9. I suffer too much when something goes wrong. & $\mathbf{3 . 6 7}$ & Agree \\
10. My promises are sacred. & $\mathbf{3 . 8 2}$ & Agree \\
\hline \multicolumn{1}{c}{ Overall scale Mean } & $\mathbf{3 . 7 3}$ & Agree \\
\hline
\end{tabular}

$\mathrm{N}=400$ Legend: 1-1.8=Strongly Disagree, 1.81-2.6=Disagree, 2.61-3.4=Neutral, 3.41-4.2=Agree, 4.21-5=Strongly Agree.

The table above shows the highest and lowest weighted mean. The first highest weighted mean is 3.89 interpreted as agree, the second highest weighted mean is 3.82 interpreted as agree, the third highest weighted mean is 3.81 interpreted as agree. The first lowest weighted mean is 3.52 interpreted as agree, the second lowest weighted mean is 3.53 interpreted as agree and the third lowest weighted mean is 3.67 interpreted as agree. The overall weighted mean is 3.73 interpreted as agree. Mean to say, most of the self-concept of the students are innately developed.

Table 4. Innately developed

\begin{tabular}{lll}
\hline Category & Frequency & Percentage \\
\hline Strongly Disagree & 0 & $0 \%$ \\
Disagree & 1 & $0.4 \%$ \\
Neutral & 25 & $10.3 \%$ \\
Agree & 155 & $63.8 \%$ \\
Strongly Agree & 62 & $25.5 \%$ \\
\hline Total & $\mathbf{2 4 3}$ & $\mathbf{1 0 0 \%}$ \\
\hline
\end{tabular}

The table above shows the number of students who develop their self-concept on the environment. The numbers of respondents who have answered strongly disagree in developing concept of self: The self is 0 or $0 \%$. Followed by the number of respondents of who have answered disagree in developing concept of self: Innately developed is 1 or $0.4 \%$. Also the number of respondents who have answered neutral in developing concept of self: Innately developed is 25 or $10.3 \%$. Then, the numbers of respondents who have answered agree in developing concept of self: Innately developed is 155 or $63.8 \%$. Lastly, the numbers 
of respondents who have answered strongly agree in developing concept of self: Innately developed is 62 or $25.5 \%$. This reveal the numbers of respondents in each category but most the respondents answered is agree in developing concept of the self: Innately developed.

Self-concept affects how a person sees his/her attitude and environment (Mishra, 2016). There are a proofs that concept of self can influence a person's perception, actions and pleasure (Beheshtifar, 2012). It turns out that the self-concept towards type of school of the students has no difference (Murugan \& Jebaraj, 2017).

Table 5. Name

\begin{tabular}{lcccc}
\hline $\begin{array}{l}\text { Nominal by Nominal } \\
\text { Lambda }\end{array}$ & Value & $\begin{array}{c}\text { Asymp. Std. } \\
\text { Error }^{\mathrm{a}}\end{array}$ & ${\text { Approx. } \mathrm{T}^{\mathrm{b}}}^{\text {Approx. }}$ & \begin{tabular}{c} 
Sig. \\
\hline $\begin{array}{l}\text { Symmetric } \\
\text { Environment }\end{array}$
\end{tabular} \\
$\begin{array}{l}\text { Dependent } \\
\text { Self }\end{array}$ & .028 & .031 & .900 & .368 \\
Dependent & .046 & .061 & .731 & .465 \\
\hline
\end{tabular}

a. Not assuming the null hypothesis

b. Using the asymptotic standard error assuming the null hypothesis

The table above shows that there is no significant correlation between developing concept of the self: the environmentally influenced or innately developed because the $p$ value $(0.465)$ is greater than significance level (0.05). If self-concept is held independent, the environment influenced the self by 0.046 or $4.6 \%$. If environmental influence is taken independent, self-concept develops innately by .011 or $1.1 \%$, but the proportion is too little to be significant. Both don't have an effect to the students in developing their self-concept because there are other factors that can more develop the students' self-concept such as age, gender, education, media and culture. Concept of self can develop the social interaction of the students. Interacting socially is the form of the students concern about their environments peace (Diswantika, 2019). Self-concept is natural it develops through interaction in the environment (Kumari \& Chamundeswaris, 2013). Self-concept of an individual is not stable it changes time by time (Demo, 1992).

\section{Summary of Findings, Conclusion, Recommendations and Limitations of the Study}

This chapter presents the findings, conclusion, and recommendations of the study.

\subsection{Findings}

This study aims to determine and evaluate the developing concept of the self: the environment and the self and to know the results of the study. The results based on the overall weighted mean reveal that the extents of the developing concept of the self: the environment is interpreted as agree which means that some of the students develop their concept because of the environment. The developing concept of the self: the self are interpreted as agree 
which means that some of the students develop their self-concept through their knowledge, experience and perception.

Using lambda the researcher found out that there is no significant correlation between developing concept of the self: environmentally influenced or innately developed.

\subsection{Conclusion}

Environment is important for the students because the environment is where the students spend most of their time and where they interact with others. Environment is also where the students can learn and gain experiences while the self-concept is generally thought of what the students think about their attitude, skills, knowledge and experiences, what the students think about the others, what the students pay much attention, how they understand the events and the challenges of their lives, and how they handle failure and success. Hence, the study is partially environmentally influenced and partially innately influenced but inadequate to be considered other factors are to specifically identified, which means that if the students don't develop their self-concept in environment and innately other intangible factors that influence the realization of students on the concept of the self.

\subsection{Recommendations}

Based on the findings and conclusion, the following are recommended.

1) Teachers should help the students to develop their self-concept. By doing this the teachers should give attention and affection to the students, so that students will develop maturity.

2) The parents must encourage and motivate their son/daughter in developing self-concept. The need enriches the student experience awaken the students' awareness of themselves to gain self-concept, so that students will develop better judgment and decision making.

3) The students must develop their own self-concept through their experience and knowledge. They must also learn to listen to the teachers, parents and peers for them to develop self-concept. Based on the findings and the discussions of this research study, the following recommendations are made.

\section{References}

Ackerman, C. (2018). What is self-concept theory? A psychologist explains. Positive Psychology. https://positivepsychology.com/

Anitha, J., \& Parameswari, G. (2013). Correlates of self-concept among high school students in chennai city, Tamilnadu, India. International Journal of Current Research and Academic Review, 1(4), 30-34. $\quad$ Retrieved from http://www.ijcrar.com/vol-4/J\%20Anitha\%20amd\%20G\%20Parameswar

Arun, L., Barreto, S., Vishwanatan, V., Makhija, A., \& Ravikumar, M. (2015). Study of self concept in relation to family environment among adolescents. The International Journal of Indian Psychology, 2(2), 58-62. 
Augestad, L. (2017). Self-concept and self-esteem among children and young adults with visual impairment: A Systematic Review. Cogent Psychology, 4, 1-12. https://doi.org/10.1080/23311908.2017.1319652

Ayodele, O. (2011). Self-concept and performance of secondary school students in mathematics. Journal of Educational and Developmental Psychology, 1(1), 176-179. https://doi.org/10.5539/jedp.v1n1p176

Bala, A. (2014). Self-concept and students academic performance in college of education akwanga, nasarawa state, Nigeria. World Young Researches, 3(2), 1-8. https://doi.org/10.1037/rnSAP0000005

Bashir, I. (2011). Pedagogical approach to enhance self-concept to the linguistically and culturally diverse classroom. World Journal of English Language, 1(1), 41-45. https://doi.org/10.5430/wjel.v1n1p41

Beheshtifar, M. (2012). Role of self-concept in organizations. European Journal of Economics and Administrative Sciences, 159-163. https://www.eurojournals.com/EJEFAS

Ceresnik, M., \& Ceresnikova, M. (2018). School self-concept of children in the system of lower secondary education in slovakia-comparison of Slovak and roma children. TEM Journal, 7(1), 211-218. https://doi.org/10.18421/TEM71-26

Cherry, K. (2019). Social comparison theory in psychology. Social Psychology. https://www.verywellmind.com/what-is-the-social-comparison-process-2795872?print

Coelho, V., Sousa, V., \& Figueira, A. (2014). The impact of a school-based social and emotional learning program on the self-concept of middle school students. Revista de Psicodidáctica, 19(2), 347-365. https://doi.org/10.1387/RevPsicodidact.10714

Davies, C., \& Lee, K. (2012). Self-concept of students in higher education: Are There Differences by Faculty and Gender? Educational Studies, (21). https://doi.org/10.1080/03055698.2012.671513

Demo, D. (1992). The self-concept over time: Research Issues and Directions. Annual Review of Sociology, 18, 303-326. https://doi.org/10.1146/annurev.so.18.080192.001511

Diswantika, N. (2019). Relationship of self concepts with social interaction of students in high schools. Advances in Social Science, Education and Humanities Research, 335. https://doi.org/10.2991/icesshum19.2019.91

Goñi, E., Madariaga, J., Axpe, I., \& Goñi, A. (2011). Structure of the personal self-concept (PSC) questionnaire. International Journal of Clinical and Health Psychology. https://www.researchgate.net/publication/286726144_Structure_of_the_Personal_Self-concep t_PSC_Questionnaire

Gore, J., \& Cross, S. (2011). Defining and measuring self-concept change. Psychological Studies, 56(1), 135-141. https://doi.org/10.1007/s12646-011-0067-0

Henderson, C., Dakof, G., Schwartz, S., \& Liddle, H. (2006). Family functioning, 
self-concept, and severity of adolescent externalizing problems. J Child Fam Stud. https://doi.org/10.1007/s10826-006-9045-x

Jaiswal, S., \& Choudhuri, R. (2017). Academic self concept and academic achievement of secondary school students. Journal of Educational Research, 5(10), 1108-1113. https://doi.org/10.12691/education-5-10-13

Joy, J. (2015). Social competence as a precursor to increased self-concept and school readiness. International Journal on New Trends in Education and Their Implications. http//www.ijonte.org/FileUpload/ks63207/File/05.a..jennifer_m_joy

Kavale, K., \& Forness, S. (2000). Self-concept of students with learning disabilities unsolicited articles related to mini-series. School Psychology Review. https://www.questia.com/library/journal/1G1-925277162

Kumari, A. (2013). Self-concept and academic achievement of students at the higher secondary level. Journal of Sociological Research, 4(2), 105-112. https://doi.org/10.5296/jsr.v4i2.3909

Laryea, J., Saani, A., \& Brew, E. (2014). Influence of students self-concept on their academic performance in the Elmina township. European Journal of Research and Reflection in Educational Sciences, $\quad 2(4), \quad 1-9$. https://www.idpublications.org/wp-content/uploads/2014/09/INFLUENCE-OF-STUDENT SELF-CONCEPT-ON-THEIR-ACADEMIC-PERFORMANCE-IN-THE-ELMINA-TOWNS HIP

Lazaro, S., Alonso, A., Gallego, D., Pol-del-Rio, M., \& Leon-del-Barco, B. (2017). Self-concept in childhood: The Role of Body Image and Sport Practice. Frontiers in Psychology, 8, 1-7. https://doi.org/10.3389/fpsyg.2017.00853

Mclnerney, D., Cheng, R., Mok, M., \& Lam, A. (2012). Academic self-concept and learning strategies: Direction of Effect on Student Academic Achievement. Journal of Advanced Academics, 23(3). https://doi.org/10.1177/1932202X12451020

Mehrad, A. (2016). Mini literature review of self-concept. Journal of Educational, Health and Community Pychology, 5(2), 61-65. https://doi.org/10.12928/jehcp.v5i2.6036

Miller, J. (2013). The role of sociability self-concept in the relationship between exposure to and concern about aggression in middle school. Research in Middle Level Education, 36(7), 1-10. https://doi.org/10.1080/19404476.2013.11462100

Mishra, S. (2016). Self- concept- a person's concept of self-influence. International Journal of Recent Research Aspects, 8-13. https://www.ijrra.net/ICCUT2016/ICCUT2016_07

Murugan, K., \& Jebaraj, J. (2017). A study of self-concept in relation to academic achievement among $9^{\text {th }}$ standard student. International Journal of Research-Granthaalayah, 5(6), 502-507. https://doi.org/10.5281/zenodo.822599

Onetti, W., Garcia, J., \& Rodriguez, A. (2019). Transition to middle school: Self-concept 
changes. PLos ONE, 14(2). https://doi.org/10.1371/journal.pone.0212640

Pesu, L., Aunola, K., Viljaranta, J., \& Nurmi, J. (2016). The development of adolescents self-concept of ability through grades 7-9 and the role of parental beliefs. Frontline Learning Research, 4(3), 92-109. https://doi.org/10.14786/flr.v4i3.249

Sampthirao, P. (2016). Self-concept and interpersonal communication. The International Journal of Indian Psychology, 3(6). http://oaji.net/articles/2016/1170- 1463651532.pdf

Sari, T., Siswad, G., \& Sriati, A. (2018). Use of social media with self-concept and social adjustment of adolescents at SMPN 2 singingi hilir riau. Asia Pacific Journal of Multidisciplinary Research, 6(2),

http://www.apjmr.com/wp-content/uploads/2018/02APJMR-2017.6.2.07

Srivastava, R., \& Joshi, S. (2011). The effect of school and area on academic self-conceptand academic achievement of adolescents. Delhi Psychiatry Journal, 14(2), 331-336. Retrieved from http://medind.nic.in/daa/t11/i2/daat11i2p331

Tice, D. (1992). Self-concept change and self presentation: The Looking Glass Self is also a Magnifying Glass. Journal of Personality and Social Psychology, 63(3), 435-450. https://doi.org/10.1037/0022-3514.63.3.435

Villegas, G., Tomasini, G., \& Lagunes, L. (2014). Development of an academic self concept for adolescents (ASCA) scale. Journal of Behavior, Health \& Social Issues, 5(2), 117-123. https://doi.org/10.22201/fesi.20070780.2013.5.2.42304

Wei, X., \& Marder, C. (2012). Self-concept development of students with disabilities: Disability Category, Gender. Remedial and Special Education, 33(4), 247-257. https://doi.org/10.1177/0741932510394872

Zhu, J., Wang, X., Liu, Z., Chen, X., \& Liu, G. (2016). The relationship between self-concept and mental health among Chinese college students: The mediating effect of social adjusting. Open Journal of Social Sciences, 4, 118-125. https://doi.org/10.4236/jss.2016.412001

\section{Appendix}

Appendix 1. Environmentally influenced

Direction: Please answer the following items honesty and rate yourself according of what statement is given. The following statements that will be gathered by the researcher will be serve as confidential.1=strongly disagree, $\mathbf{2}=$ disagree, $\mathbf{3}=$ neutral, $\mathbf{4}=$ agree, $\mathbf{5}=$ strongly agree.

\begin{tabular}{|r|r|r|r|r|l|}
\hline & $\mathbf{5}$ & $\mathbf{4}$ & $\mathbf{3}$ & $\mathbf{2}$ & $\mathbf{1}$ \\
\hline 1. I depend on other people. & & & & & \\
\hline 2. If I'm feeling down, I always need a friend to lean on. & & & & & \\
\hline 3. In order to do anything, I first need other people's approval. & & & & & \\
\hline 4. I find it hard to do anything without other people's support. & & & & & \\
\hline 5. I am more sensitive than the majority of people. & & & & & \\
\hline
\end{tabular}




\begin{tabular}{|c|l|l|l|l|l|}
\hline $6 . \quad$ I suffer too much when other people ignores me. & & & & & \\
\hline 7. I try not to do anything that may hurt others. & & & & & \\
\hline $\begin{array}{l}\text { 8. I find it difficult to make decisions without other people's } \\
\text { opinion. }\end{array}$ & & & & & \\
\hline 9. I am more honest than other people. & & & & & \\
\hline $\begin{array}{l}\text { 10. I know how to make decisions without other people's } \\
\text { suggestion. }\end{array}$ & & & & \\
\hline
\end{tabular}

Reference:

https://www.researchgate.net/profile/lnge_Axpe/publication/286726144_structure_of_the_personal_s elf_concept_PSC_Questionnaire/links/56b45826608ae5deb2658160b/Structure-of-the

Personal-Self-Concept-PSC-Questionnaire.pdf?origin=publication_detail

Appendix 2. Innately developed

Direction: Please answer the following items honesty and rate yourself according of what statement is given. The following statements that will be gathered by the researcher will be serve as confidential. $\mathbf{1}$ =strongly disagree, $\mathbf{2}=$ disagree, $\mathbf{3}=$ neutral, $\mathbf{4}=$ agree, $\mathbf{5}=$ strongly agree.

\begin{tabular}{|l|l|l|l|l|l|}
\hline & $\mathbf{5}$ & $\mathbf{4}$ & $\mathbf{3}$ & $\mathbf{2}$ & $\mathbf{1}$ \\
\hline 1. I am satisfied with what I am achieving in my life. & & & & & \\
\hline 2. So far, I have achieved every important goal I have set on myself. & & & & & \\
\hline 3. I am a trustworthy person. & & & & & \\
\hline $\begin{array}{l}\text { 4. I have always overcome any difficulties I have encountered in my } \\
\text { life. }\end{array}$ & & & & \\
\hline 5. I am a decent, honest person. & & & & & \\
\hline $6 . \quad$ If I could start my life over again, I would not change very much. & & & & & \\
\hline 7. I am a strong person. & & & & & \\
\hline $8 . \quad$ I feel proud of how I am managing my life. & & & & & \\
\hline $9 . \quad$ I suffer too much when something goes wrong. & & & & & \\
\hline 10. My promises are sacred. & & & & & \\
\hline
\end{tabular}

Reference:

https://www.researchgate.net/profile/lnge_Axpe/publication/286726144_structure_of_the_personal_s elf_concept_PSC_Questionnaire/links/56b45826608ae5deb2658160b/Structure-of-the

Personal-Self-Concept-PSC-Questionnaire.pdf?origin=publication_detail

\section{Copyright Disclaimer}

Copyright for this article is retained by the author(s), with first publication rights granted to the journal.

This is an open-access article distributed under the terms and conditions of the Creative Commons Attribution license (http://creativecommons.org/licenses/by/3.0/). 